\title{
Haemangioma on Tongue: A Case Report
}

\author{
Chaithra Kalkur* and Nilofer Halim \\ Department of Oral Medicine \&Radiology, Century International Institute of Dental Science \& Research Centre, India
}

Submission: July 05, 2017; Published: August 22, 2018

*Corresponding author: Chaithra Kalkur, Department of Oral Medicine \& Radiology, Century International Institute of Dental Science \& Research Centre, Poinachi, Kasargod, Kerala, India, Tel: 09448815455; Email: chaithra.kalkur@gmail.com

\begin{abstract}
Hemangiomas are seen most commonly on cheeks, upper lip and upper eyelids on head and neck while they are observed in very small proportions on tongue. Surgery, corticosteroids, sclerosing agents, radiation therapy, diathermy, electrocauterization, cryosurgery, embolization, laser, radiofrequency, and interferon are used in treatment of hemangiomas. This case reports a case of haemangioma on the right later border of the tongue in a 38-year-old male.
\end{abstract}

Keywords: Hemangioma; Electrocauterization; Cryosurgery; Embolization; Laser; Radiofrequency

\section{Introduction}

Hemangioma is a proliferation of the endothelial cells which lines vascular channels. It is a benign developmental abnormality, characterized by onset during infancy and regresses as the patient ages [1]. The development of Hemangioma takes place in three phases: proliferating, involution, and involuted. Hemangioma appears as a red macula, papule or nodule, depending on the congestion degree and on how deep it is in the tissue [2].

Hemangiomas can be classified as superficial, deep or compound. The superficial hemangioma/Strawberry or capillary hemangioma is red and nodular with no subcutaneous component. A deep hemangioma/or Cavernous hemangioma is a protrusion with an overlying telangectasia. Compound hemangiomas/or Capillary cavernous hemangioma compraises of both deep and superficial components [3].

Tongue hemangioma is a rare benign vascular tumor that causes bleeding, difficulty in breathing, chewing and speaking and pain. Hemangiomas commonly seen on skin, $80 \%$ of these appear as single lesions, while $20 \%$ are bilateral lesions. Male to female ratio is 1:3. Hemangiomas are seen most commonly on cheeks, upper lip and upper eyelids on head and neck [4].

\section{Case Report}

A 38-year-old male presented with complain of swelling in the mouth involving the right lateral border of the tongue since five years. The swelling in the tongue gradually increased to the present size. Pain, fever, difficulty in the speech and swallowing or any other associated features were absent. Past medical, dental and family histories were non-significant. Physical general examination was normal with all his vital signs being within normal limit.
Intra-oral examination (Figure 1) revealed a solitary domeshaped swelling in the right anterior part of tongue extending both dorsally and ventrally, measuring about $2 \times 2.5 \mathrm{~cm}$ in size. The surface was smooth and granular with well-defined borders. Colour of the swelling was bluish purple with normal surroundings. Swelling was soft to firm on palpation, non-mobile, non-tender, and normal in temperature with no appreciable thrills but blanched on compression.

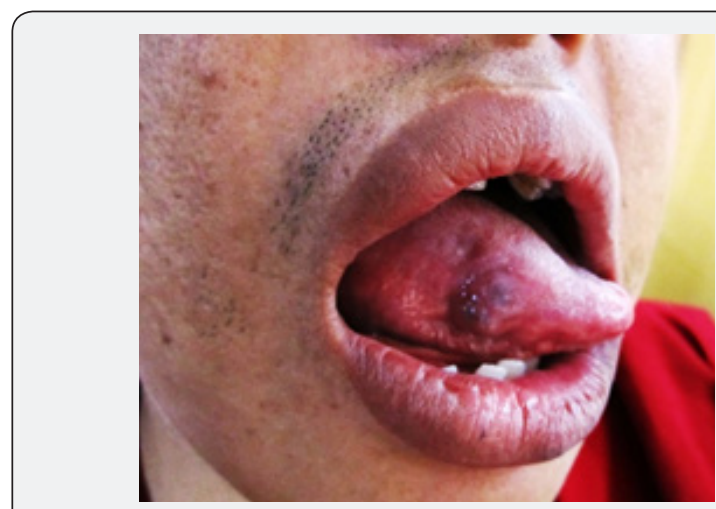

Figure 1: Showing extension of lesion on tongue.

Patient was diagnosed as a case of haemangioma with differential diagnosis of lymphangioma, angiomyolipoma, angiosarcoma, hemangiosarcoma and Kaposi's sarcoma. Patient advised for surgical opinion, but patient didn't follow up later.

\section{Discussion}

Haemangioma is a blood vessel tumor. The word "Haemangioma" is derived from the Greek word, where 'haema' means blood, 'angio' means vessel and oma means tumour. This is a tumor seen in infancy and in most cases appear during the 
first few days or weeks of life \& resolve within the age of 10years [5]. Hemangiomas grow with cellular proliferation. In this $7 \%$ of tumors are benign. $70-90 \%$ of them are seen in the first $1-4$ weeks [6].

Intraoral lingual hemangiomas causes cosmetic deformity, functional problems with speaking, deglutition, mastication and recurrent haemorrhage [7]. Clinical appearance as a soft, smooth or lobulated, sessile or pedunculated and may be seen in any size. The colour of the lesion ranges from pink to red purple and tumour blanches on the application of pressure, and haemorrhage may occur either spontaneously or after minor trauma. They are generally painless [8].

There are several reports suggested the etiology of hemangioma. The proliferation of haemangioma is because of estrogen signalling [8]. According to North et al. suggested placental theory of haemangioma based on various histology and molecular markers like GLUTI, Lewis Y Antigen, Merosin, CCR6, CD15, IDO, FC, and gamma Receptor II. Recent theory suggested as haemangioma growth is related to somatic mutational events in gene involved in angiogenesis. VEGF, b-TGF, and IGF are the growth factors specifically involved in angiogenesis during the proliferation phases of haemangioma [9].

Many haemangiomas disappear without treatment, leaving minimal or no visible marks. Large haemangiomas can leave visible skin changes secondary to severe stretching of the skin or damage to surface texture. Facial lesions in particular, nose and lips need cosmetic surgery [10].

Management of haemangioma includes surgery, corticosteroids, sclerosing agents, radiation therapy, diathermy, electrocauterization, cryosurgery, laser, embolization, radiofrequency, and interferons. Total excision is difficult and high chances of recurrences are seen. Corticosteroids should be applied only in selected cases due to systemic side effects. Radiotherapy regresses hemangiomas, but it causes severe atrophy on tissues of the treated area especially on skin. For superficial lesions Cryotherapy can be applied [4].

\section{Conclusion}

Haemangioma in the oral cavity is of clinical importance. It often mimics other lesion clinically and requires appropriate clinical diagnosis and proper management.

\section{References}

1. Kauzman A, Pavone M, Blanas N, Bradley G (2004) Pigmented Lesions of the Oral Cavity: Review, Differential Diagnosis, and Case Presentations. J Can Dent Assoc 70(10): 682-683.

2. Corrêa PH, Nunes LCC, Johann ACBR, Aguiar MCF, Gomez RS, et al. (2007) Prevalence of oral hemangioma, vascular malformation and varix in a Brazilian population. Braz Oral Res 21(1): 40-45.

3. Richter GT, Friedman AB (2012) Hemangiomas and Vascular Malformations: Current Theory and Management. Int J Pediatr 2012: 645678.

4. Bozan N, Gür MH, Kıroğlu AF, Çankaya H, Garça MF (2014) Tongue Hemangioma: A Case Report. Van Tip Dergisi 21(2): 120-122.

5. Neville BW, Damm DD, Allen CM, Bouqot (2002) Oral and Maxillofacial Pathology. ( $\left.2^{\text {nd }} e d n\right)$, Philadelphia, WB Saunders, USA.

6. Phung TL, Hochman M, Mihm MC (2005) Current knowledge of the pathogenesis of infantile hemangiomas. Arch Facial Plast Surg 7(5): 319-321.

7. Brown DA, Smith JD (1987) Late complication of congenital hemangioma of the tongue. Head Neck Surg 9(5): 299-304.

8. Bonet-Coloma C, Mínguez-Martínez I, Palma-Carrió C, Galan-Gil S, Penarroche-Diago M, et al. (2011) Clinical characteristics, treatment and outcome of 28 oral hemangiomas in pediatric patients. Med Oral Patol Oral Cir Bucal 16(1): e19-e22.

9. Gill JS, Gill S, Bhardwaj A, Grover HS (2012) Case Report: Oral Haemangioma. Case Reports in Medicine 2012(347939): 1-4.

10. Singh R, Agarwal SP, Sinha ON, Gaur S (2016) A Case Report-Inj Polidocanol in Haemangioma of Tongue. Sch J App Med Sci 4(7B): 2433-2435.

\section{Your next submission with Juniper Publishers will reach you the below assets}

- Quality Editorial service

- Swift Peer Review

- Reprints availability

- E-prints Service

- Manuscript Podcast for convenient understanding

- Global attainment for your research

- Manuscript accessibility in different formats

( Pdf, E-pub, Full Text, Audio)

- Unceasing customer service

Track the below URL for one-step submission https://juniperpublishers.com/online-submission.php 